\title{
Climate change implications for the glaciers of the Hindu Kush, Karakoram and Himalayan region
}

\author{
A. J. Wiltshire \\ Met Office Hadley Centre, Exeter, Devon, EX1 3PB, UK \\ Correspondence to: A. J. Wiltshire (andy.wiltshire@metoffice.gov.uk) \\ Received: 13 June 2013 - Published in The Cryosphere Discuss.: 23 July 2013 \\ Revised: 21 March 2014 - Accepted: 27 March 2014 - Published: 22 May 2014
}

\begin{abstract}
The Hindu Kush, Karakoram, and Himalaya $(\mathrm{HKH})$ region has a negative average glacial mass balance for the present day despite anomalous possible gains in the Karakoram. However, changes in climate over the 21 st century may influence the mass balance across the HKH. This study uses regional climate modelling to analyse the implications of unmitigated climate change on precipitation, snowfall, air temperature and accumulated positive degree days for the Hindu Kush (HK), Karakoram (KK), JammuKashmir (JK), Himachal Pradesh and West Nepal regions (HP), and East Nepal and Bhutan (NB). The analysis focuses on the climate drivers of change rather than the glaciological response. Presented is a complex regional pattern of climate change, with a possible increase in snowfall over the western $\mathrm{HKH}$ and decreases in the east. Accumulated degree days are less spatially variable than precipitation and show an increase in potential ablation in all regions combined with increases in the length of the seasonal melt period. From the projected change in regional climate the possible implications for future glacier mass balance are inferred. Overall, within the modelling framework used here the eastern Himalayan glaciers (Nepal-Bhutan) are the most vulnerable to climate change due to the decreased snowfall and increased ablation associated with warming. The eastern glaciers are therefore projected to decline over the 21 st Century despite increasing precipitation. The western glaciers (Hindu Kush, Karakoram) are expected to decline at a slower rate over the $21 \mathrm{st}$ century in response to unmitigated climate compared to the glaciers of the east. Importantly, regional climate change is highly uncertain, especially in important cryospheric drivers such as snowfall timing and amounts, which are poorly constrained by observations.

Data are available from the author on request.
\end{abstract}

\section{Introduction}

The high mountains of South Asia covering the Hindu Kush, Karakoram and Himalaya (HKH) belt have been described as the "Water Tower of Asia" (Viviroli et al., 2007; Immerzeel et al., 2010) due to their important role in feeding the major rivers of South Asia. Water resources are considered vulnerable in the region due to the important role of snow and ice in the hydrology of the region (Barnett et al., 2005). Seasonal storage of water in snow and ice acts to delay the timing of runoff (Kaser et al., 2010; Immerzeel et al., 2010; Siderius et al., 2013; Schaner et al., 2012). The retreat and loss of glaciers may therefore have a significant impact on the quantity and timing of water availability as is currently observed in parts of the tropical Andes (Rabatel et al., 2013).

The vulnerability of water resources to climate change is further enhanced due to the coincidence of a large and growing population. For example, the Indus originates in the Tibetan plateau and carries melt water from the glaciated Karakoram and Jammu-Kashmir region to a highly populated region. The flow component arising from glacial discharge is highly uncertain and estimates vary from $40 \%$ for the upper Indus (Immerzeel et al., 2010) to as low as $2 \%$ in one of the glaciated sub-catchments (Jeelani et al., 2012). However, seasonally, there is potentially a very large population reliant on glacier discharge (Schaner et al., 2012). Regionally over 1.4 billion people depend on water from the Indus, Ganges, Brahmaputra, Yangtze, and Yellow rivers (Moors et al., 2011; Immerzeel et al., 2010) which arise in the HKH and Tibetan plateau (not considered here), although the influence of glacier discharge will decrease with distance downstream and river flow will become more influenced by precipitation variability (Kaser et al., 2010). There 
is correspondingly a need to better quantify the potential impacts of climate change on regional water resources.

The HKH have attracted controversy over reported rates of glacier ice loss. The IPCC WGII AR4 (Cruz et al., 2007) reported an erroneous statement from WWF (2005) that glaciers may disappear by 2035 (Cogley et al., 2010) with significant implications for water resources. More recent work has shown that in some parts of the region glaciers have been increasing in mass over the last decade - the "Karakoram anomaly" (Hewitt, 2005; Gardelle et al., 2013). There are few direct observations from the region (Bolch et al., 2012) but a number of recent studies have demonstrated that the glaciers of the HKH have experienced negative mass balance overall in the last decade (1999 to 2011) (Jacob et al., 2012; Kääb et al., 2012; Gardelle et al., 2013; Gardner et al., 2013). A study by Fujita and Nuimura (2011) looking at three benchmark glaciers found evidence of rapid glacier wastage since the 1970s. The humid lower glaciers have a more negative mass balance than the arid high-elevation benchmark glacier, implying that the lower glaciers are more sensitive to change. Observational data suggest that the change in glacier state is spatially heterogeneous across the region $(\mathrm{Fu}-$ jita and Nuimura, 2011) potentially due to climate (Fowler and Archer, 2006) and glaciological and locational factors, such as elevation and glacier debris cover (Scherler et al., 2011). The Karakoram anomaly relates to a sub-region of the HKH in which glaciers may have increased mass or remained relatively stable over the last decade (Gardelle et al., 2012; Hewitt, 2005, 2011; Kääb et al., 2012; Gardelle et al., 2013) in contrast to other parts of the HKH. Evidence for the Karakoram anomaly comes from other sources - for instance Fowler and Archer (2006) found evidence of a cooling trend between 1961 and 2000 consistent with glacier thickening. Copland et al. (2011) found evidence of increased glacier surging in the 1990s compared with previous decades consistent with increased precipitation. The only in situ data source for the Karakoram indicates an average budget of $-0.51 \mathrm{~m} \mathrm{year}^{-1}$ w.e. for Siachen Glacier (1986 to 1991) (Bhutiyani, 1999). It should be noted that all these results are based on limited observations from which regional trends are difficult to infer. A study using satellite altimetry data (Kääb et al., 2012) revealed a complex pattern in mass balance (Table 1), with the Karakoram glaciers thinning by only a few centimetres a year with greater rates of loss in the Hindu Kush and the central and eastern Himalayas. The greatest rates of loss were found in the Jammu-Kashmir region. Recent updates are broadly in agreement but found that the Karakoram anomaly extended further northwest into the Pashmir region, and higher rates of mass loss in the eastern Himalayas (Gardelle et al., 2013; Gardner et al., 2013).

Although some evidence points to climate change as a potential cause of the Karakoram anomaly, other explanations include the existence of large areas of debris cover on Karakoram glaciers which may reduce sensitivity to change (Scherler et al., 2011) and thus contribute to the spatial het- erogeneity, although Kääb et al. (2012) and others found no evidence for this. Snow avalanches may also be an important mass balance component in the Karakoram due to the steep and rugged terrain (Hewitt, 2011).

The spatial heterogeneity in mass balance is therefore likely to be partly linked to spatial variation in climate change and variability, the short length of observational mass balance data available and the variation in glaciological conditions. Other non-climatic drivers such as deposition of dust and soot may also play a role, with some evidence that this may already be having an effect on some Tibetan glaciers (Xu et al., 2009).

There are relatively few studies that aim to make a comprehensive assessment of the future glacier state under climate change. A global study by Radić and Hock (2010) focused on sea-level rise found an average ice volume loss of $10 \pm 16 \%$ between 2000 and 2100 under the SRES A1B scenario. The large uncertainty in their result spanning a possible increase to decrease is related to the future regional climate uncertainty (Cruz et al., 2007; Meehl et al., 2007). The uncertainty is further exacerbated by the complex orography of the HKH which is not captured in coarse-scale global climate models. However, the possibility of a future increase in glacier volume as found by Radić and Hock (2010) highlights the importance of changing precipitation patterns and the potential for increasing snowfall under global warming. This in turn may offset any increased ablation due to warming, possibly leading to glacier thickening and advance in some regions under some scenarios.

This study aims to increase understanding of the potential impacts of climate change on the glaciers of the Himalayas and Hindu Kush. In particular the issue of the relative roles of changing accumulation and ablation in the context of climate uncertainty are addressed. A regional climate model (RCM) is employed to downscale global GCM climate simulations under the SRES A1B scenario (Nakicenovic et al., 2006), and produce a best estimate of the present day by down-scaling ERA-Interim reanalysis (Dee et al., 2011). The simulations are performed at $25 \mathrm{~km}$ in an attempt to capture the complex role of orography whilst retaining computationally efficacy. Two GCM simulations are used from models shown to capture the dynamics of the monsoon; the two models are chosen to sample the spread in precipitation uncertainty from a possible future increase to a decrease. Due to the general lack of quality observational data across the high mountains the ERA-Interim simulation is used as a benchmark against which to evaluate the GCM derived simulations of the future. The application of RCMs to regions of complex topography remains challenging, partly due to their relatively coarse resolution in comparison to topography. However, the ERAInterim simulation has been shown to well represent the role of steep topography on moisture transport fluxes and vertical flow for the western Himalayas (Dimri et al., 2013), and the GCM-driven models have been shown to capture the synoptic patterns influencing winter precipitation in the region. 
Table 1. Elevation statistics by region as used in the RCM at $25 \mathrm{~km}$ resolution and derived from the GMTED2010 high-resolution elevation data set (in brackets) (Danielson and Gesch, 2011). Also shown are the satellite-derived glacier mass balance 2003-2009 from Kääb et al. (2012).

\begin{tabular}{lrrrr}
\hline & $\begin{array}{r}\text { Mean } \\
\text { elevation } \\
\text { (m a.s.1.) }\end{array}$ & $\begin{array}{r}\text { Maximum } \\
\text { elevation } \\
\text { (m a.s.1.) }\end{array}$ & $\begin{array}{r}\text { Minimum } \\
\text { elevation } \\
\text { (m a.s.l.) }\end{array}$ & $\begin{array}{r}\text { Mass } \\
\text { m w.e. year }\end{array}$ \\
\hline Hindu Kush & $3779(4067)$ & $4737(7794)$ & $2645(2501)$ & $-0.2 \pm 0.06$ \\
Karakoram & $4885(4972)$ & $5835(8216)$ & $3647(2502)$ & $-0.03 \pm 0.04$ \\
Jammu-Kashmir & $4128(4293)$ & $5263(6728)$ & $2519(2501)$ & $-0.55 \pm 0.08$ \\
Himachal Pradesh, Uttarakhand and West Nepal & $4616(4622)$ & $6142(7751)$ & $2532(2502)$ & $-0.32 \pm 0.06$ \\
East Nepal and Bhutan & $4734(4700)$ & $5951(8642)$ & $2568(2501)$ & $-0.3 \pm 0.09$
\end{tabular}

Overall, the use of regional climate modelling over the Indian subcontinent has been shown to significantly improve the regional detail of projected climate change (Lucas-Picher et al., 2011; Mathison et al., 2013; Kumar et al., 2006, 2013).

The simulations are analysed in terms of the possible future climate drivers of glacier accumulation and ablation across the $\mathrm{HKH}$ in the context of climate uncertainty and spatial heterogeneity. As this study is focused on the climatic drivers, other factors that may influence the complex glaciological response such as debris cover, common within the Himalayas, are not considered. Detection and attribution of recent changes in mass balance is not within the scope of this study.

\section{Baseline regional climate}

The climate of South Asia is characterised by the strong meridional temperature gradient between the high mountains of the HKH and the subcontinent of India (Fig. 1). The climate of the HKH is heavily influenced by three circulation systems; Western Disturbances (WD), the Indian Summer Monsoon (ISM) and the East Asian Monsoon (EAM). These three systems are largely responsible for the patterns of seasonal precipitation that can be seen in Fig. 2, with much of the precipitation in the region occurring over the extended summer monsoon months (May to October). The region has a strong temperature contrast, with the high mountains having an annual mean temperature below $0^{\circ} \mathrm{C}$, and the lower plains in excess of $20^{\circ} \mathrm{C}$. Across the Himalayan arc the Karakoram Range is cooler, related to on average higher altitudes, than the rest of the region (Table 1, Fig. 1).

The WD bring moisture from the Mediterranean Sea over the northwestern parts of the Indian subcontinent. The system is particularly responsible for bringing snowfall during the winter and pre-ISM months. The ISM brings moisture from the Bay of Bengal, causing intense rainfall over the region during the summer months, and is partly linked to snowfall during the summer months towards the eastern end of the Himalayan arc (Fig. 3). The influence of the ISM decreases strongly further west of approximately $\sim 77^{\circ} \mathrm{E}$ in the
Garhwal Himalayas (Bookhagen and Burbank, 2006, 2010), separating the Jammu-Kashmir (JK) region from Himachal Pradesh, Uttarakhand and West Nepal (HP). West of this divide precipitation is dominated by WD with the ISM having a diminishing role.

The mountains of the Himalayan arc provide a barrier to the northward progression of moisture, separating the plains of South Asia from the relatively dry Tibetan Plateau to the north (Fig. 2). Some moisture is able to move north through the deep valleys cut by rivers flowing south to join the Ganges. The rise of the Himalayan arc through the foothills to the high Himalayas leads to considerable orographic uplift and thus considerable precipitation along the orographic barrier (Dimri et al., 2013).

The combination of the interaction between the circulation systems and the Himalayas, as well as elevation and latitudinal differences, leads to a strong gradient in precipitation from the Hindu Kush (HK) in the West to Nepal-Bhutan (NB) in the East, as well as a strong gradient from the Himalayan foreland into the Tibetan Plateau. There is less of a gradient in total snowfall along the $\mathrm{HKH}$ arc but there is a variation in the seasonal timing of snowfall. The regions further west $(\mathrm{HK}, \mathrm{KK})$ are dominated by winter accumulation with summer snowfall also playing a role further east in the Nepal-Bhutan region (Fig. 3). The glaciers in the east (NB) are therefore monsoon influenced experiencing some summer accumulation, whilst those to the west are primarily winter accumulating $(\mathrm{HK}, \mathrm{KK})$. The timing of potential melt as defined by seasonality of air temperature is less spatially variable, with all regions demonstrating summer ablation. This has important implications for seasonal water storage and water resources. The eastern glaciers are monsoon influenced and experience some additional summer accumulation, as well as summer ablation, and therefore do not store water seasonally to the same extent as the western glaciers (HK, KK). These monsoon-affected summer accumulation glaciers may also be more vulnerable to warming (Fujita, 2008a, b) as any increase in ambient temperature is likely to have a double effect; increasing potential melt as well as decreasing the likelihood of precipitation falling as snow. This is due to the overall higher summer ambient temperature 

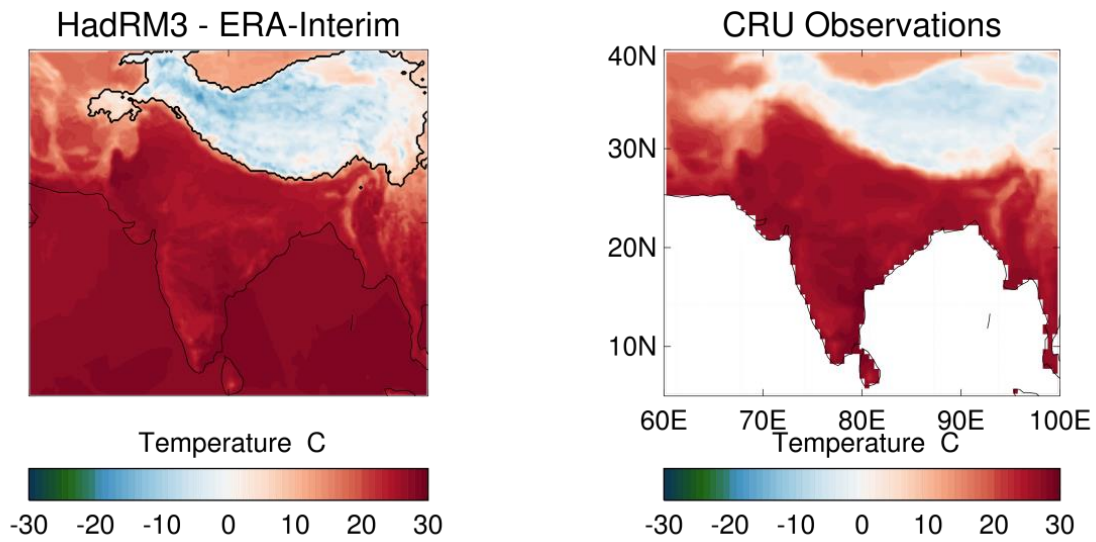

Figure 1. Annual mean air temperature of the Indian Subcontinent (1992-2007) as simulated by downscaling ERA-Interim reanalysis using the HadRM3 regional climate model compared to CRU observations. The region above $2500 \mathrm{~m}$ a.s.l. is indicated. Note that the RCM data are on a rotated pole projection.
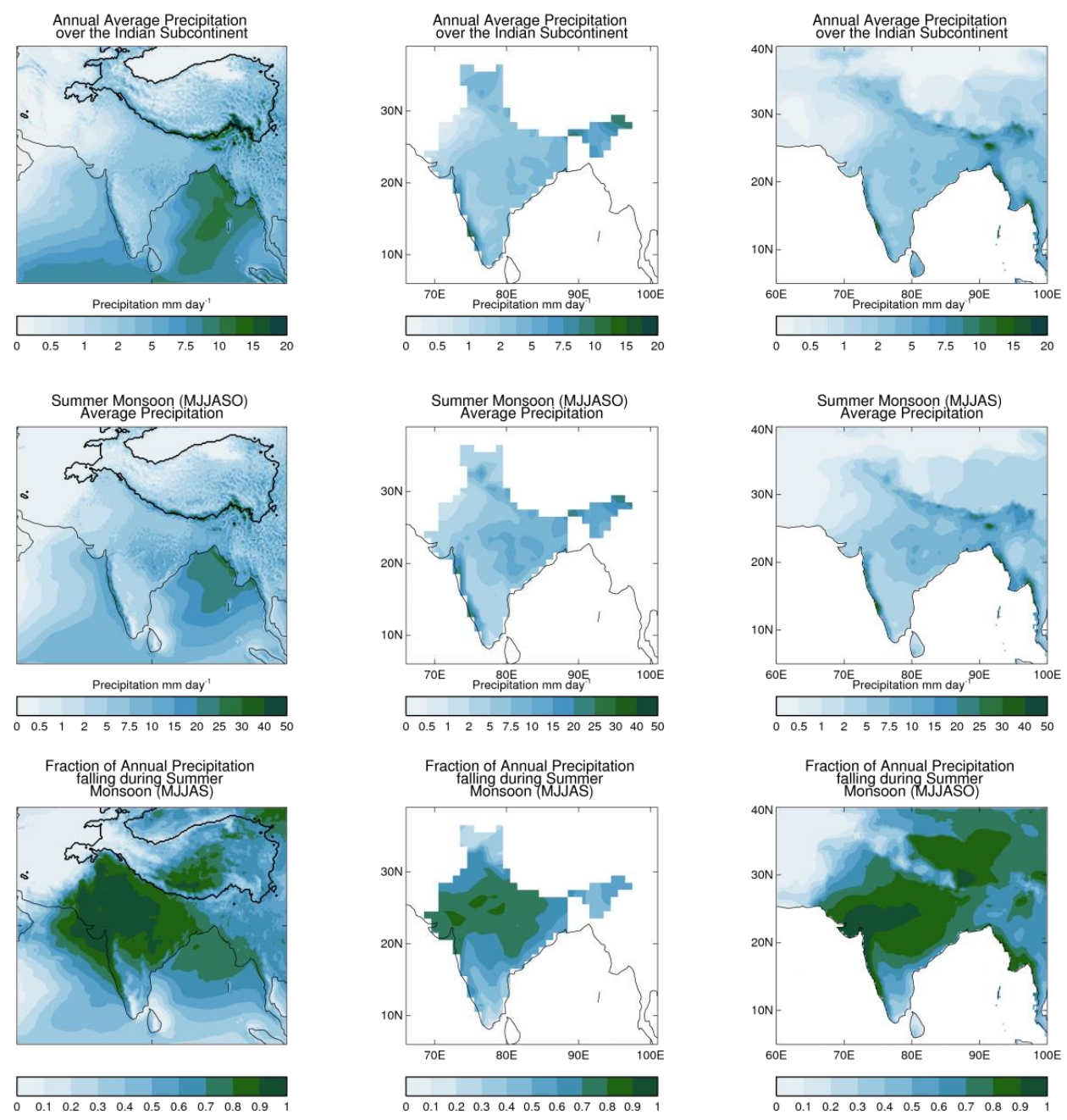

Figure 2. Precipitation over the Indian Subcontinent (1992-2007) as simulated by downscaling ERA-Interim reanalysis using the HadRM3 regional climate model compared against observation data from the Indian Meteorological department (Rajeevan et al., 2008) and Aphrodite (Yatagai and Yasunari, 1994). The $2500 \mathrm{~m}$ a.s.l. contour is shown on the left-hand plots. Note that the RCM data are on a rotated pole projection. 
compared to the winter. Any warming is therefore likely to increase the number of days above the critical threshold of $0^{\circ} \mathrm{C}$ more in the summer than in the winter.

\section{Methods}

This study employs regional climate modelling of selected global climate projections to simulate the spatial heterogeneous patterns in meteorology across the HKH that may be driving some of the variation in mass balance. This study uses regional climate models (RCMs) to both simulate the present-day climatology of the HKH as well as make centennial projections of climate change. The aim is not to make direct future projections of mass balance but to assess projections of the climate drivers of mass balance, namely simulated precipitation, temperature and snowfall. The majority of the results presented here are therefore in anomaly space as multi-decadal means relative to the present day (e.g. results for the 2080s are the mean 2071-2100 climate anomalised to 1992-2008). However, it is not possible to work entirely in anomaly space in confidence without some evaluation of present-day model biases. An overview evaluation of the present-day model biases is therefore included to add confidence in the future simulated change. Regional climate biases are currently an unavoidable shortcoming in global climate models.

Snowfall is used as a measure of change in the future accumulation of glaciers, and from daily air temperature positive degree days (PDDs) are calculated. PDDs can be linked to potential melt through degree day factors (Hock, 2003, 2005). A PDD is defined as the cumulative sum of daily mean temperatures over $0^{\circ} \mathrm{C}$ for a month. Temperature index modelling using degree days is thus a simplification of complex processes controlling the energy balance at the surface. The basis for degree day modelling is the observed close relationship between air temperature and melt (Ohmura, 2001; Hock, 2003). Temperature index models are therefore widely used and can perform well in comparison with energy balance models at large scales (Hock, 2005).

\subsection{Regional climate modelling}

The porosity of spatially explicit meteorological observation data across the HKH region is a significant barrier to understanding the climate interactions with the HKH cryosphere. For instance, there are few precipitation gauges within the Himalayas (Bookhagen and Burbank, 2010; Yatagai et al., 2009). For this region Akhtar et al. (2008) found a better performance with a hydrological model when using RCM data than when using poor-quality observation data implying greater confidence in the RCM simulated meteorology than available observational data. Global observation data sets are typically coarse and do not capture the complex topography in the region (Kang et al., 2002). For this reason the HadRM3 RCM (HadRM3 is a regional version of the HadAM3 global atmosphere model (Pope et al., 2000; Gordon et al., 2000). The version used here is coupled to the MOSES2.2 land surface scheme (Essery et al., 2003) and is employed to dynamically downscale ERA-Interim reanalysis (Dee et al., 2011). This provides a baseline of the present day climate to assess the climate simulations against. The meteorological reanalysis provides a consistent estimate of the atmospheric state of the recent past, and the downscaled product is thus our best estimate of the climate state despite additional errors and uncertainty from the reanalysis process and the downscaling itself (Lucas-Picher et al., 2011). The downscaled ERA-Interim scenario enables the evaluation of the regional climate biases in the climate simulations. The scenario can also be evaluated in conjunction with available observations to assess the ability of the RCM to accurately simulate climate over complex terrain. To capture both the role of orography and the large-scale regional circulation the climate simulations are run at $25 \mathrm{~km}$ for the whole Indian subcontinent (Fig. 1). Although this resolution is fine in terms of centennial climate simulations for most regions, in the Himalayas $25 \mathrm{~km}$ is not fine enough to resolve topography. Other applications of numerical modelling in the high mountains have focused on the shorter weather timescales and have employed significantly higher resolutions in the order of kilometres (e.g. Maussion et al., 2011). Associated, explicit modelling of the microclimate over glaciers also requires an atmospheric modelling setup in the kilometre resolution (e.g. Collier et al., 2013; Molg and Kaser, 2011). The choice of $25 \mathrm{~km}$ is therefore a necessary compromise between the desire to sample climate uncertainty in the form of an ensemble, length of simulation, available supercomputer time (one centennial simulation consumes approximately four months of supercomputer time) and the resolution necessary to appropriately resolve orographic processes. For context, the decision to use 25 as opposed to $50 \mathrm{~km}$ increased the computational requirement by a factor of 8 , and correspondingly reduced the number of ensemble members possible to sample uncertainties. Additionally, in order to sample future climate uncertainty two global climate model (GCM) simulations are downscaled covering 1960-2100 for the SRES A1B scenario (Nakicenovic et al., 2006). The two scenarios are from versions of ECHAM5 (Roeckner et al., 2003) and HadCM3 (Pope et al., 2000; Gordon et al., 2000). The impact of climate change on the ISM is considerably uncertain in the IPCC AR4 CMIP3 (IPCC, 2007) ensemble with model responses varying on the sign of the direction of change (Christensen et al., 2007). Climate models also show significant differences in their ability to simulate the ISM in the present day (Annamalai et al., 2007). Some of the future uncertainty may therefore be associated with models with a lack of skill in simulating the ISM. Of the CMIP3 ensemble only four models were shown to be able to capture the large-scale statistics of the ISM under the present climate (Annamalai et al., 2007; Kripalani et al., 2007; Turner and 

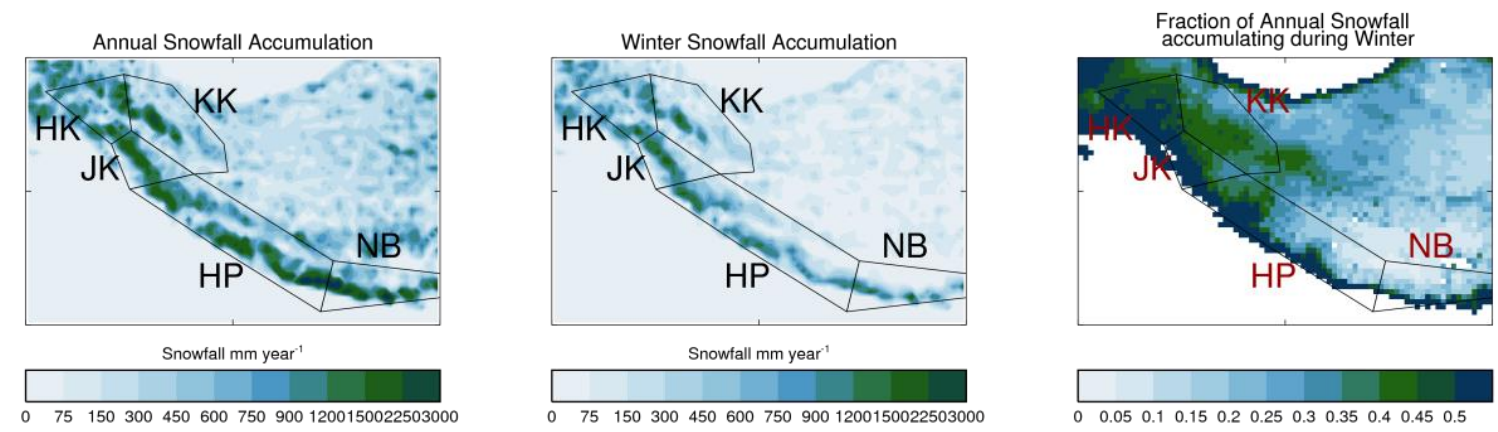

Figure 3. Annual snowfall accumulation along the Himalayan belt (left), winter snowfall (December to March) accumulation (centre) and the fraction of annual snowfall occurring during the winter. Data are 1992-2008 averages from ERA-Interim downscaled with the HadRM3 regional climate model.
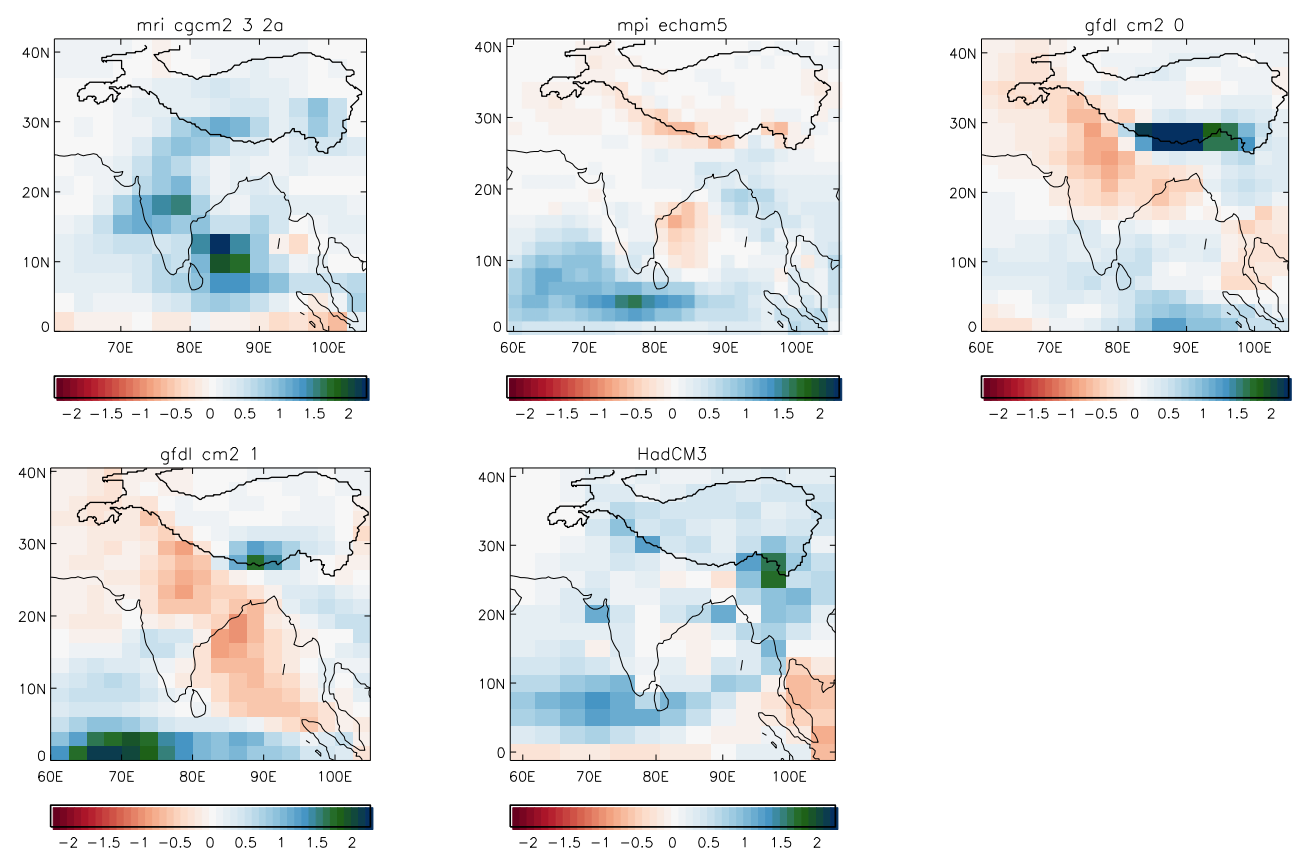

Figure 4. Change in precipitation (mm per day) by the 2080s relative to 1961-1990 under the SRES A1B scenario for four selected CMIP3 models and a flux-corrected version of HadCM3. The region above $2500 \mathrm{~m}$ a.s.1. is indicated.

Annamalai, 2012). The uncertainty in the monsoon precipitation response to global warming is related to two key opposing processes responding to global warming: the thermodynamic forcing whereby atmospheric moisture content increases, and the dynamical weakening of the monsoon due to weakening of circulation patterns (Ueda et al., 2006).

The standard CMIP3 HadCM3 model was not able to capture the monsoon dynamics. However, a version of HadCM3 using flux correction performed better. The flux adjustment of HadCM3 improved the mean state of the tropical Pacific improving the simulation of ENSO, this in turned improved the monsoon-ENSO relationship and the overall simulation of the ISM (Turner et al., 2005). There are therefore five possible GCMs available that are considered able to capture the monsoon dynamics (Fig. 4) critical to appropriately simu- lating the impact of climate change on the high-mountain cryosphere of South Asia. In this study the ECHAM5 and flux-corrected HadCM3 simulations are used, chosen to sample uncertainty in the sign of projected precipitation change. ECHAM5 simulates a decrease in precipitation for the $\mathrm{HKH}$ region and HadCM3 an increase.

\subsection{Sub-regional definitions and baseline glacier state}

To understand the spatial variation in climate drivers and in glacier mass balance, distinct sub-regions across the $\mathrm{HKH}$ are defined to capture the variation in climate and observed glaciological patterns. Following the classification of Kääb et al. (2012) the five sub-regions are defined as (Table 1 and Fig. 5): Hindu Kush (HK), Karakoram (KK), 
Jammu-Kashmir (JK), Himachal Pradesh, Uttarakhand and West Nepal (HP) and East Nepal and Bhutan (NB). In further analysis the sub-regions above $2500 \mathrm{~m}$ a.s.l. are used to form area averages. The majority of the glaciers in the study region are covered by the extended World Glacier Inventory (WGI) (Cogley, 2010) whilst the Randolph (RGI) (Arendt et al., 2012) data set provides a complete coverage. The use of regional definitions consistent with Kääb et al. (2012) allows the use of the mass balance observations as a baseline from which to assess the possible impacts of climate change (Table 1).

One of the significant challenges in using RCMs to analyse the implications of climate change on glacier mass balance is the ability to resolve glaciers which are typically at the subgrid scale. The RCM simulates meteorological fields at the elevation of the grid box mean. A second challenge is parameterising the sub-grid variation in topography effect on meteorology. The model has too coarse a resolution to resolve mesoscale processes such as convection and small-scale valley flows which affect motions of vertical flow important to snow rainfall discretisation and instead rely on parameterisations. Figure 5 shows the topography in the GMTED2010 high resolution (30 arcsec) (Danielson and Gesch, 2011) alongside the elevation data as used in the RCM (processed 10 min data, US Navy, 1980). A comparison of the areaaltitude distribution from the two fields reveals that the RCM captures the elevation distribution across the $\mathrm{HKH}$ domain in the more up-to-date higher resolution product; however at elevations above $4500 \mathrm{~m}$ the RCM data is biased a few hundred metres high but low compared to elevations in excess of $5500 \mathrm{~m}$. This bias is introduced by the smoothing of steeply varying topography in this region. Further analysis shows that the standard deviation of sub-grid topography can reach up to $1500 \mathrm{~m}$ in some grid boxes where the topography rises steeply. The impact of topography smoothing is further affected by the likelihood of glaciers to be biased high compared to the grid box mean elevation. An analysis of the GLIMS glacier topography inventory (Raup et al., 2007; GLIMS, 2005) reveals that for some parts of the region the mean glacier elevation can be up to $2500 \mathrm{~m}$ above the RCM grid box mean. In a few cases the grid box mean is up to $750 \mathrm{~m}$ above the mean glacier elevation. The GLIMS data (inventory version glims_db_20130813) were used for this purpose as topographic information is available as part of the inventory. However, GLIMS elevation data represent only a subset of all the glaciers in the RGI with gaps in most regions and virtually no altitude information for $\mathrm{KK}$ and $\mathrm{HK}$. An important caveat to the results presented here is that they are based on grid box mean elevations which have an inherent elevation bias to the glaciers of the HKH. This limitation and inherent climate biases in regional climate modelling is the reason why this study focuses on the climate drivers of change rather than attempting to simulate mass balance directly.

\section{Results}

\subsection{Simulations of the recent past}

In this section the ability of the RCM simulations to capture the climate of the recent past is evaluated. The ERA-Interim simulation captures the large-scale features in temperature and precipitation (Figs. 1 and 2). Across the HKH region there is a cold bias relative to the CRU temperature data set. The annual and monsoon precipitation is well captured in the RCM compared with IMD (Rajeevan et al., 2008) and Aphrodite (Yatagai et al., 2009) observations (Fig. 2). The fraction of annual precipitation that falls during the monsoon is also reasonably simulated. A close analysis of precipitation over the HKH suggests that the RCM has a wet bias at high elevations. However, there is a significant lack of observations in particular at high elevations and the observed bias may be enhanced due to the lack of gauge under catch corrections in the Aphrodite data. PDDs and snowfall are particularly sensitive to biases in temperature and precipitation and are difficult to evaluate in the absence of high-resolution spatially explicit observations. The climatology for these variables over the key regions for the recent past is shown in Fig. 6.

Across all regions temperatures peak above $0{ }^{\circ} \mathrm{C}$ during the summer with strong within-region variation associated with the large variation in altitude. The KK is significantly colder in the winter, with NB the warmest due to latitudinal differences despite similar elevations (Table 1). NB also shows the least seasonal variation in temperature. The GCM driven runs show small biases in temperature relative to ERA-Interim, suggesting that any systematic bias is introduced by the downscaling rather than the forcing. However, small differences in temperature can have a large influence on the number of PDD, with HadCM3 simulating a factor of a third more in the summer compared to ERA-Interim. Small biases are seen in the other regions, with the lower HK and JK regions having higher degree days than the other regions. NB, HP and JK also show small numbers of positive degree days in the winter despite mean winter temperatures of -15 to $-20^{\circ} \mathrm{C}$.

The timing and amount of precipitation varies strongly with region. The highest precipitation occurs in NB during the summer monsoon. Further west, where WD prevail, peak precipitation falls in the spring. The more central JK region is affected by both western disturbances and the monsoon with a double peak in precipitation. The GCMs show a similar pattern to ERA-Interim with ECHAM5 showing some bias in the timing and magnitude of peak monsoon precipitation.

Accurately simulating snow/rain differentiation in RCMs, particularly in regions of complex terrain, is significantly challenging and the models are likely to be significantly limited in their ability to capture this. Of the climate drivers presented here snowfall amounts are likely to be most uncertain. In KK, HK and JK snowfall mainly occurs during the 


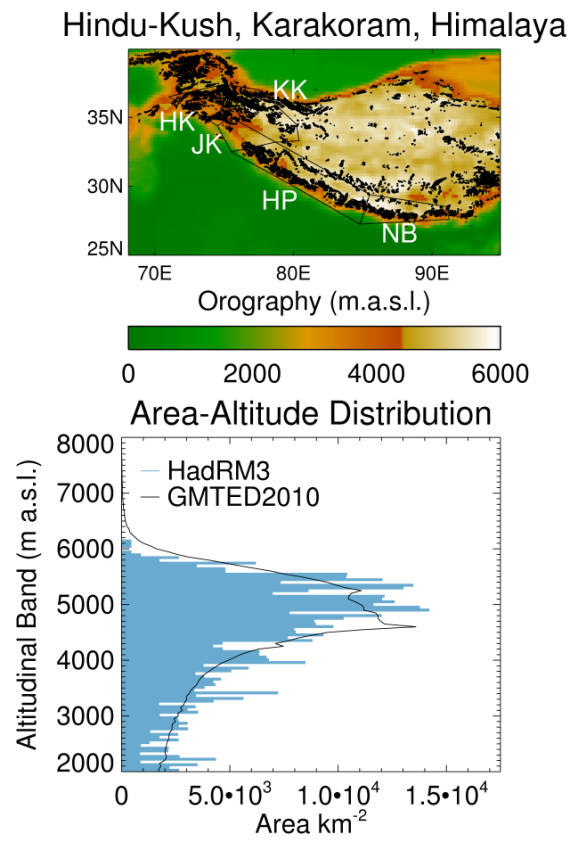

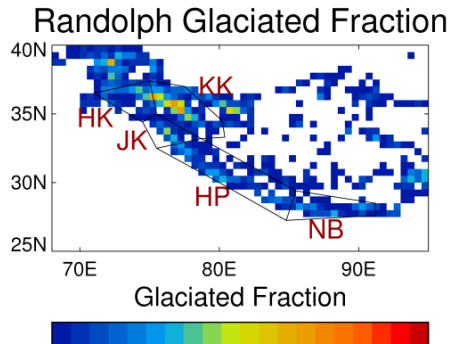

$0 \quad 0.10 .20 .30 .40 .50 .60 .70 .80 .91$

Figure 5. Location map of the Hindu Kush, Karakoram and Himalaya region showing the location of glaciers from the extended World Glacier Inventory (Cogley, 2010) (left), and the glaciated fraction aggregated to half degree from the Randolph glacier inventory (Arendt et al., 2012) (right). Also shown is the area-altitude distribution as used in the RCM and from the high-resolution GMTED10 (Danielson and Gesch, 2011) product. Highlighted are the Hindu Kush (HK), Karakoram (KK), Jammu-Kashmir (JK), Himachal Pradesh, Uttarakhand and West Nepal (HP) and East Nepal and Bhutan (NB) sub-regions used in this study.

winter months associated with western disturbances (Ridley et al., 2013). However, the more central and eastern HP and NB show significant summer snowfall, with strong disagreement between models. Despite the lack of long-term observations a measurement campaign along a elevation crossing the Annapurna range found little summertime snowfall (Putkonen, 2004). The maximum observed snow accumulation of $1000 \mathrm{~mm}$ of snow water equivalent (SWE) at high elevations is comparable to the $\sim 900 \mathrm{~mm}$ SWE snowfall simulated in HP, implying too much summer snowfall and not enough during the winter. Amongst the models there is some disagreement in the volume of snowfall occurring during the winter. The timing and volume of snowfall is likely to be very sensitive to the cold and wet biases in the model.

Although the simulations show variation in climate between the sub-regions this doesn't allow an inference on the climate role in observed trends in mass balance, rather it suggests that the glaciers of the region most likely have differing characteristics associated with varying climatic regime. To infer the role of climate change over the late 20th and early 21 st century requires a different approach to attribute the detected changes in mass balance to a shift in climate. Instead, the projected changes over the 21 st century as drivers of cryospheric change are analysed.

\subsection{Projected changes in HKH climate}

Over the 21st century under the SRES A1B emissions scenario the $\mathrm{HKH}$ region is projected to warm by $4-5.5^{\circ} \mathrm{C}$ relative to 1971-2000 (Fig. 7). This is a faster rate of warming than the global and regional rates of increase. This is partly due to the land warming faster than the oceans and reductions in the simulated seasonal and perennial snow cover decreasing the surface albedo. The ECHAM5 simulation has the higher rate of warming, which may be linked with the greater reductions in snowfall and seasonal snow cover in this simulation. In both simulations the majority of the HKH remains below freezing but there is an increase in the height of the annual mean zero degree isotherm. For all regions and both models the rate of warming is greatest during the winter months. However, the seasonal warming differs between the models with ECHAM5 showing uniform warming for KK, $\mathrm{HK}$ and $\mathrm{JK}$ of around $5^{\circ} \mathrm{C}$ by the $2080 \mathrm{~s}(30 \mathrm{yr}$ mean centred on 2085) whilst $\mathrm{HadCM} 3$ gives $3^{\circ} \mathrm{C}$ in spring but nearly $6^{\circ} \mathrm{C}$ in the winters (Figs. 8 and 9). The trend in temperature change is similar between models and regions until the 2050s at which point ECHAM5 has a stronger rate of warming than HadCM3 (Fig. 10).

Although rapid warming is projected in the HKH this doesn't necessarily translate into higher rates of ablation. The index of ablation used here is positive degree days above zero (PDD). Changes in PDD are highest where this is a seasonal 

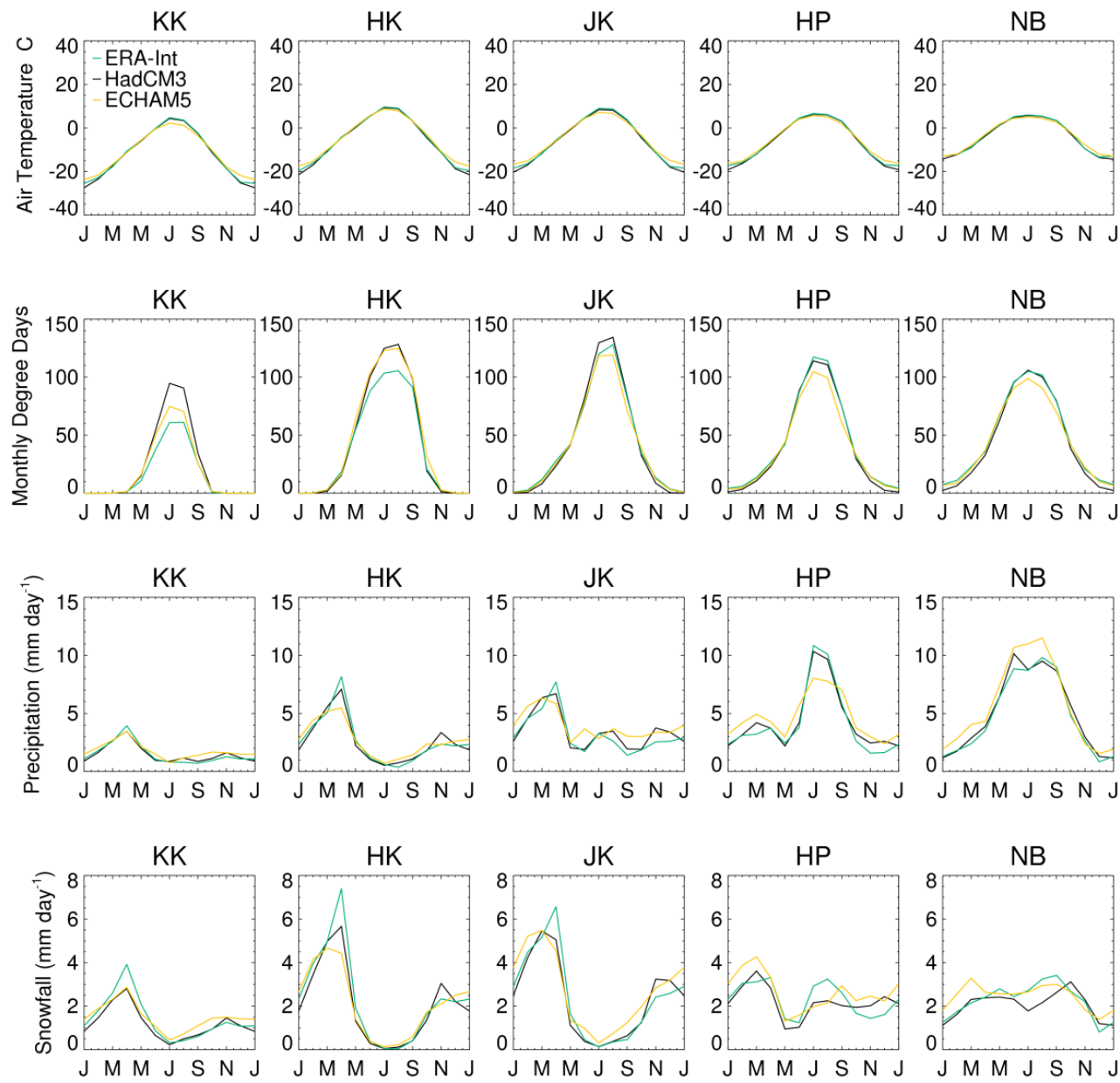

Figure 6. Thirty-year mean climatologies of air temperature, PDDs, precipitation and snowfall for the five sub-regions defined in this study from the downscaled ERA-Interim (green), HadCM3 (black) and ECHAM5 (yellow) simulations for 1992-2008. The regions are Hindu Kush (HK), Karakoram (KK), Jammu-Kashmir (JK), Himachal Pradesh, Uttarakhand and West Nepal (HP) and East Nepal and Bhutan (NB).

transition in air temperature from below freezing to above. Relatively very cold regions and very hot regions will show small changes in PDD. This can be seen in Fig. 7, which shows that the greatest increases are in the mountains, with small changes across the Indo-Gangetic plain. The highest and coldest parts of the HKH show small changes in PDD. The biggest annual increase in PDD occurs in NB and HP associated with a broadening of the potential melt season with significant increases during the winter. This broadening is linked to the winters being warmer than the rest of the $\mathrm{HKH}$, so that any climate warming leads to a larger increase in PDD. By the 2080s the mean temperature difference between the ECHAM5 and HadCM3 simulations in HK and JK is around 0.5 to $1{ }^{\circ} \mathrm{C}$; however this small temperature change corresponds to a substantially bigger increase in positive degree days and thus potential melt (Fig. 10).

Changes in precipitation show a more complex and uncertain response, with models showing regional variation in the sign and magnitude of change despite an overall agreement of an increase in precipitation for the region as a whole. HadCM3 simulates the strongest increases in precipitation in the western regions (HK, JK, KK) whilst ECHAM5 shows a strong increase in NB. Significantly, ECHAM5 gives a small decrease in JK and HK by the 2080s implying uncertainty over the sign of change in this region. The two models deviate from around the 2020s with HadCM3 showing a continual increase in precipitation whilst the trend in ECHAM5 reverses and declines. This reversal is linked to a jump in PDD (less so in mean temperature). This difference between the two models is mainly linked to uncertainty in both the monsoon and WD simulated by the two models. However, increased precipitation doesn't necessarily lead to increasing rates of accumulation. Changes in snowfall amounts are a better indicator of possible changes in accumulation. By the 2080s the two simulations show an overall decrease in snowfall across the HKH with the greatest decreases around 


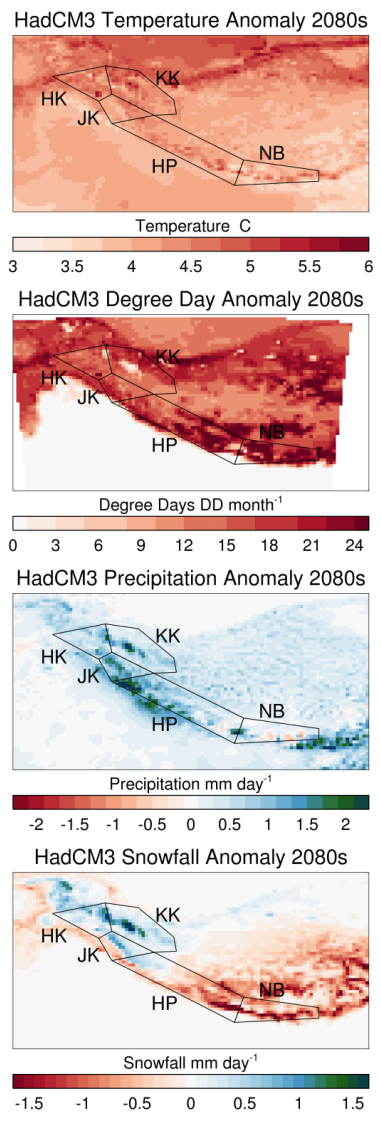

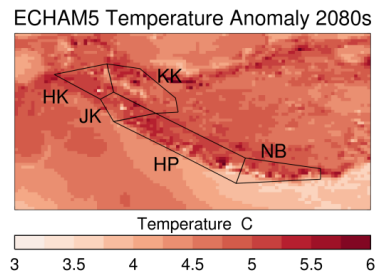

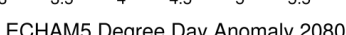
ECHAM5 Degree Day Anomaly 2080s
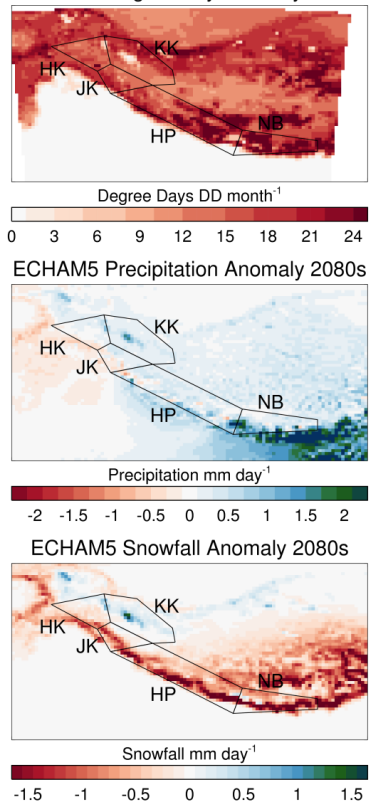

Figure 7. Projected changes in regional climate by the 2080s relative to 1992-2008 from the downscaled HadCM3 and ECHAM5 A1B simulations. Plots show change in annual average temperature, degree days, precipitation and snowfall.

the zero-degree isotherm. The HadCM3 simulations have an overall increase in KK, HK and JK whilst ECHAM5 only had an increase in the highest parts of KK. A study by Ridley et al. (2013) found that this could partly be explained by changes in circulation with HadCM3 simulating increased occurrence of WD, with an associated overall $37 \%$ increase in winter snowfall, whilst ECHAM5 showed no change in occurrence of WD. Both models show a strong decrease in snowfall in the HP and NB regions despite an overall increase in precipitation. In HadCM3 the decrease in snowfall is concentrated in the summer months, but ECHAM5 includes decreases in winter snowfall.

\section{Discussion}

\subsection{Climate drivers of future mass balance}

The modelling performed here reveals a complex pattern of climatic change across the HKH corresponding to changes in circulation patterns and regional warming. All sub-regions have an increase in potential ablation. The western part of the

HKH (HK, KK, JK) may have an increase in accumulation, although this is highly uncertain. In contrast, the eastern part of the HKH (HP, NB) shows a decrease in accumulation in both ensemble members (Figs. 8 and 9) due in part to a substantial reduction in the fraction of precipitation falling as snow, despite an overall increase in precipitation. However, it is possible that the model is over-estimating snowfall for the present day and therefore over-estimating the magnitude of decline in the future.

Taking these climate drivers as indicators of change in the cryosphere, plausible inferences can be made on the effect on future glacier mass balance, despite the models not fully resolving glaciers. The glaciers in the HP and NB are monsoon influenced and summer accumulating with winter accumulation types dominating in KK and HK. The summers show the largest increases in PDD despite the winters having a comparatively greater warming (Figs. 8 and 9). The increase in PDD in the HP and NB coincide with the timing of snowfall. Therefore, despite an intensification of the precipitation in the east (NB, HP), less of the precipitation falls as snow and thus accumulation decreases. These monsoonaffected glaciers may therefore be more vulnerable to warming as any increase in ambient temperature is likely to have a double effect: increasing potential melt as well as decreasing the likelihood of precipitation falling as snow (Fujita, 2008a, b). This implies that glaciers in NB and HP may be more vulnerable to warming than glaciers in other parts of the $\mathrm{HKH}$ for similar levels of warming.

The glaciers in the NB and HP (in the absence of glaciological factors) may see greater reductions in their mass balance than in HK, KK and JK. Despite ongoing warming, glaciers in the west may have increased accumulation seemingly dependent on changes in the frequency and intensity of western disturbances although this is uncertain. This increase in snowfall by the 2080s in HadCM3 is offset by a large increase in possible ablation. In contrast, by the 2080s there is a decrease in snowfall simulated by ECHAM5.

The combined effect of increased potential ablation and snowfall on mass balance can be estimated in terms of a simple degree day factor. A degree day factor is defined as the melt per PDD. A simple degree day factor can be calculated for a zero change in mass balance over the $21 \mathrm{st}$ century for the KK region, such that changes in accumulation are balanced by melt. This can then be compared to those derived from observations. The factor for the KK region is $0.5 \mathrm{~mm}$ w.e. $\mathrm{d}^{-1}{ }^{\circ} \mathrm{C}^{-1}$. This is an order of magnitude smaller than calculated for the Dokriani glacier (Hock, 2003; Singh et al., 2000) in HP which for clean snow is $5.7 \mathrm{~mm}$ w.e. $\mathrm{d}^{-1}{ }^{\circ} \mathrm{C}^{-1}$. It is correspondingly unlikely in this scenario that increasing accumulation will offset increasing melt in the HadCM3 scenario. Given this, and that present mass balance is approximately neutral in the KK, it seems likely, in these scenarios, that climate-driven changes in future mass balance will be negative. This is the case for the whole HKH including the KK. 

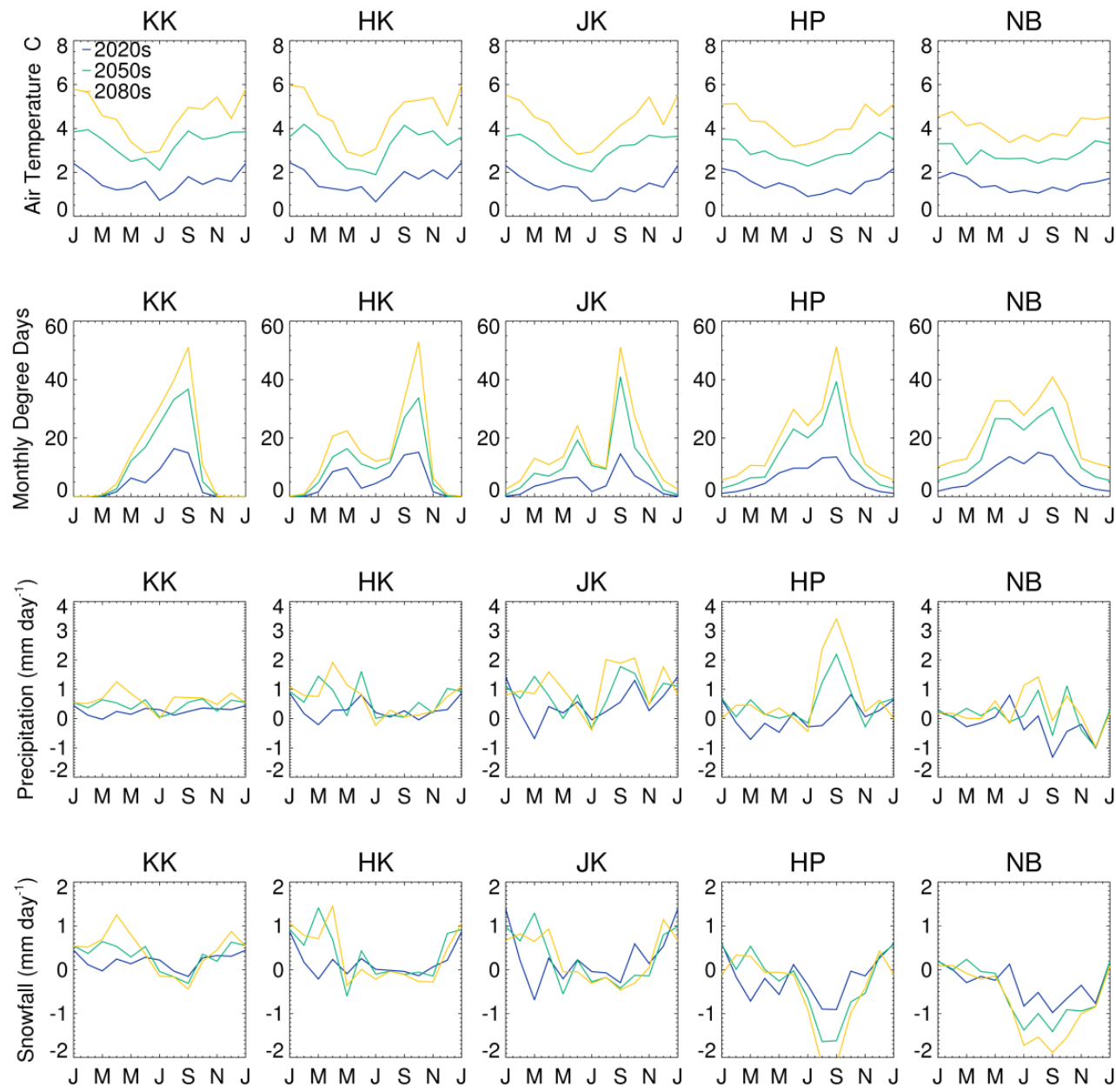

Figure 8. Thirty-year mean climatologies of air temperature, PDDs, precipitation and snowfall for the five sub-regions defined in this study from the downscaled HadCM3 A1B scenario. Shown are $30 \mathrm{yr}$ climatologies for, 2020s (blue), 2050s (green) and 2080s (yellow) anomalised to 1992-2008. The regions are Hindu Kush (HK), Karakoram (KK), Jammu-Kashmir (JK), Himachal Pradesh, Uttarakhand and West Nepal (HP) and East Nepal and Bhutan (NB).

The results presented here based on climate drivers of change imply a gradient from low to high rates of mass loss from west to east (KK to NB). This is in broad agreement with observations of absolute changes in mass balance for the last decade (Gardelle et al., 2013; Gardner et al., 2013; Kääb et al., 2012). However, the satellite studies find the greatest mass loss rates the JK which are not consistent in magnitude with the climate drivers. This may be because either different processes dominate in the future or perhaps due to the limitations of this study including the failure to consider the actual distribution of glaciers at the present time and the absence of glaciological response modelling to the climate drivers. Of particular note is the role of debris cover and glacier topography in altering the glaciological response to climatic change. Although debris-covered glaciers have been shown to have thinning rates comparable to debris-free glaciers (Nuimura et al., 2012; Bolch et al., 2011) this may be in response to different drivers. This highlights the need for detailed glacier response modelling to projected climate change to fully understand the implications of climate change.

Within the projections presented here there is the large amount of inter-annual variability seen in snowfall across the region. The variability in accumulation and ablation as well as the non-equilibrium state of glaciers means that the longterm mean glacier mass balance may be considerably different from that derived from the short satellite record. The ECHAM5 simulation (Figs. 11 and 12) shows an increase in snowfall in HK and JK in the 2020s despite an overall decline by the 2080s. This is associated with a moderate degree of warming, thus raising the counter-intuitive possibility that for small amounts of warming, snowfall may increase in the western part of the HKH. The aforementioned Karakoram anomaly and associated glacier thickening may therefore be consistent with an overall warming trend in the region, although it should be noted that this requires further investigation and is highly uncertain. 

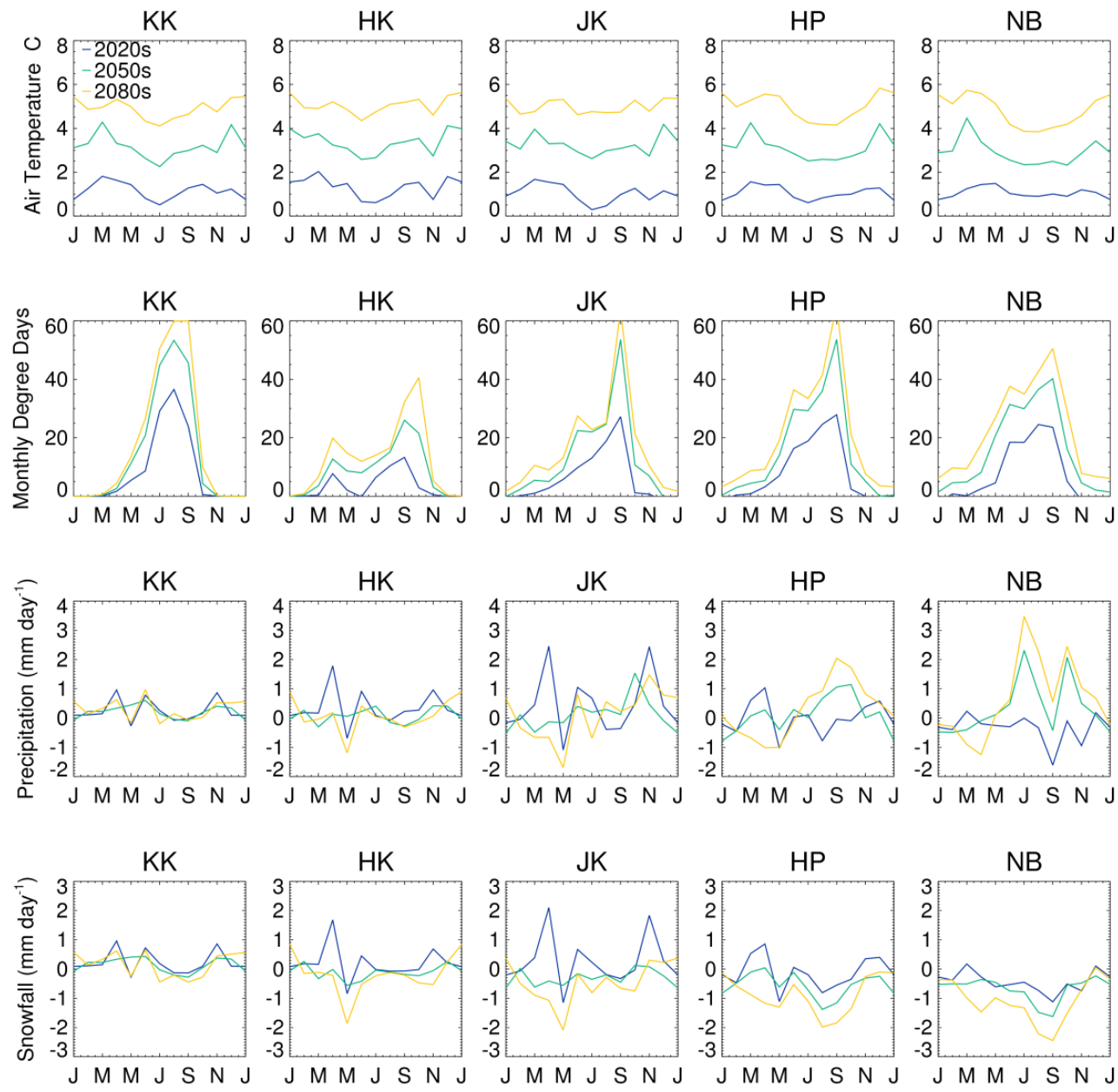

Figure 9. Thirty-year mean climatologies of air temperature, PDDs, precipitation and snowfall for the five sub-regions defined in this study from the downscaled ECHAM5 A1B scenario. Shown are $30 \mathrm{yr}$ climatologies for the 2020s (blue), 2050s (green) and 2080s (yellow) anomalised to 1992-2008. The regions are Hindu Kush (HK), Karakoram (KK), Jammu-Kashmir (JK), Himachal Pradesh, Uttarakhand and West Nepal (HP) and East Nepal and Bhutan (NB).

Some studies have found the rate of warming to increase with elevation in the Himalayas and Tibetan plateau (e.g. Liu and Chen, 2000) stabilising around $5000 \mathrm{~m}$ a.s.l. (Qin et al., 2009). However, the magnitude and mechanisms driving this phenomenon remain unclear and uncertain (Kang et al., 2010). In the simulations analysed here the high mountains in general warm faster than the Indo-Gangetic plain. This may be due to snow-albedo feedbacks as seasonal and perennial snow covers change but also changes in circulation patterns affecting the advection of warm air into the mountains. However, there is no consistent pattern of a correlation in warming level and elevation above $2500 \mathrm{~m}$ a.s.l, but rather a strong seasonal uncertainty in the magnitude of projected warming.

\subsection{Water resources}

The overall impact of a declining future glacier mass balance on future water resources is complicated by the glaciological response, in which glaciers retreat to form new more stable equilibrium. The initial response may be increased wastage and thus an initial increase in runoff - the de-glaciation dividend. However, this reduces as glaciers form new stable states (Collins, 2008). A major driver of change in the eastern HKH is the decline in snowfall; however, this is due to a switch from snow to rain and is accompanied with an overall increase in precipitation. This, combined with the low seasonal storage of water in the snowpack (coincidence of summer accumulation and summer ablation) implies that renewable water resources are likely to increase under climate change. This is not necessarily the case in the western part of the HKH, which is a major source of runoff for the populated Indus. The projections given here span a possible decrease to increase in precipitation. In this case, the Indus might be more sensitive to changes in glacier mass and extent than other rivers of the region. This may be significant as the Indus 

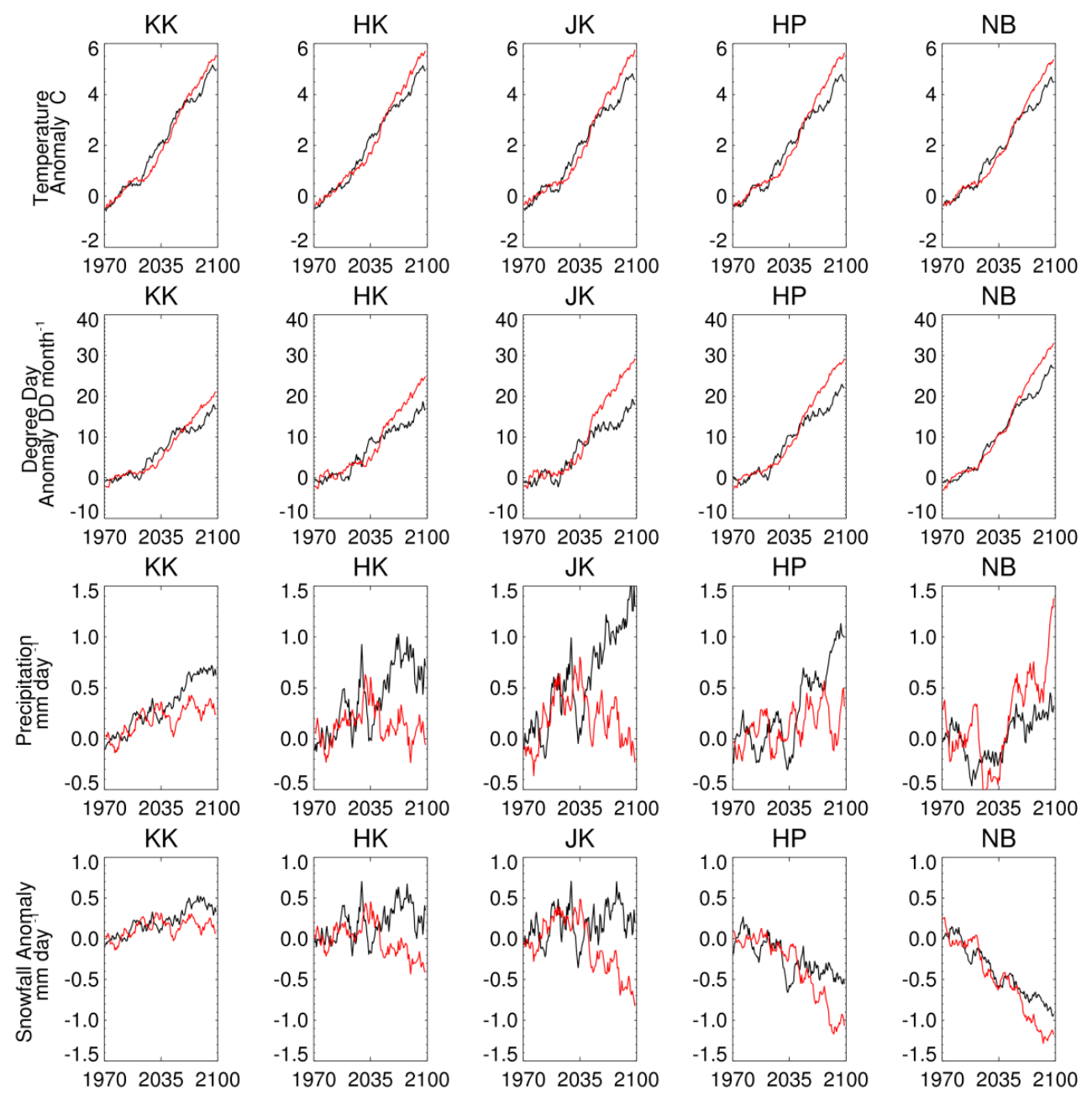

Figure 10. Projected change in annual mean air temperature, PDDs, precipitation and snowfall from the HadCM3 (black) and ECHAM5 (red) downscaled A1B simulations. Data are anomalies over the 21st century relative to 1992-2008. Data are smoothed with a 10 year moving average. The regions are Hindu Kush (HK), Karakoram (KK), Jammu-Kashmir (JK), Himachal Pradesh, Uttarakhand and West Nepal (HP) and East Nepal and Bhutan (NB).

population is thought to be vulnerable to change in water resources (Schaner et al., 2012).

\subsection{Regional climate modelling limitations}

It should be noted that there are a number of important caveats to the results presented here. Modelling the climate in areas of complex terrain, such as the HKH, is a difficult task, particularly when making long-term climate projections which require large amounts of computer power. In particular, the ability of the RCM to capture snow/rain fractionation is likely to be poor, particularly given the large sub-grid variation in topography. It has also been shown that the model may have a cold, wet bias potentially leading to an overestimation in the present-day summer snowfall. In turn this may implicate an overestimation of the degree to which ablation is projected to decrease. The RCM microphysics sim- ulates the fall of snow and rain through the atmosphere with a conversion of snow to rain through sublimation and melt. The final snowfall is calculated for the grid box mean elevation. Another factor in the ability of the model to capture the snow/rain split in precipitation is the simulation of vertical motion. Rasmussen et al. (2011) found in a coarser resolution $(36 \mathrm{~km})$ model that the strong vertical motion associated with gravity waves forming due to flow over topography were not captured as well as in the $6 \mathrm{~km}$ model. The strong up- and down-drafts are associated with snow as opposed to rainfall, and result in less snowfall in a coarser model despite overall similar levels of precipitation (Rasmussen et al., 2011; Ikeda et al., 2010). The RCM used here employs parameterisations of gravity waves and convection to address these unresolved processes. It is unclear whether these parameterisations are likely to increase or decrease snowfall compared to a model explicitly resolving these processes. However, what is clear 
in the modelling applied here is that the relatively coarse resolution of the RCM is unable to appropriately capture the variation in topography. Furthermore, given computational limitations, this study only considers two GCMs and as can be seen in Fig. 4 the projected climate change in the Himalayas is uncertain on the sign of change in precipitation despite an ability to appropriately simulate the present-day monsoon. It is therefore the case that the two ensemble members given here do not fully sample the present-day range of uncertainty in the large-scale circulation over the Indian subcontinent under climate change.

To better understand the possible impacts of climate on the Himalayas requires improved observational data sets to better constrain model processes for the present day. In addition, the latest generation of atmospheric models which are able to use a spatially variable grid resolution provide the opportunity to run simulations that are able to resolve topography, explicitly capturing convection and gravity wave formation, the distribution of glaciers and large-scale circulation changes associated with climate change. These tools may help both understand the past changes in glaciers and their associated drivers as well as better constrain future projections (Molg and Kaser, 2011). Furthermore, developments of GCMs through higher resolution and improved process representation may help reduce climate biases and lead to improved projections of regional climate change. New highresolution reanalysis products, such as the High Asia Reanalysis (Maussion et al., 2014) produced using numerical weather prediction techniques, can go some way to filling this data void.

\section{Conclusion}

In this study a pair of moderate-resolution regional climate simulations is used to capture the implications of unmitigated climate change on the atmospheric environment of the HKH cryosphere. The implications of climate on accumulation and ablation are complex and spatially variable and likely to be affected by model resolution. To fully investigate these interactions requires high-resolution physically based modelling to capture the important role of orography in the region. The lack of observational data limits the possible evaluation of climate model performance but this study finds that downscaling meteorological reanalysis data provides a reasonable evaluation for the climate simulations. However, projected changes, particularly declines in future snowfall, are very sensitive to a possible high bias in present-day snowfall. The results presented here can be seen as a first step to assessing the implications for regional climate. More detailed atmospheric and glacier modelling are required to make a more complete assessment.

Overall, using the model framework this study finds that NB and HP Himalayas are likely to be more vulnerable to unmitigated climate change than glaciers in the Hindu Kush and Karakoram. This is because, in the scenarios presented here, NB and HP glaciers accumulate mass during the summer monsoon, which brings snowfall to the region, and are relatively warmer in comparison to the HK and KK, which have a larger degree of winter accumulation. The effect of warming is twofold: first, to decrease the fraction of precipitation falling as snow and, second, to increase the rates of ablation. The magnitude of changes in snowfall under climate change is highly uncertain. The increase in potential ablation is linked to both an increase in the melt period as well as its intensity.

It is therefore projected that the eastern Himalayas will have a stronger negative regional trend in mass balance than the central KK. However, the highest regions of mass loss in the baseline observations were for the western Himalayas inconsistent with the future trends presented here (Kääb et al., 2012; Gardelle et al., 2013). However, other studies support higher values of mass loss in the eastern Himalayas (Gardner et al., 2013; Neckel et al., 2014). The results presented here lend support to these high rates of mass loss continuing into the future.

The Western HKH shows possible increases in snowfall and thus mass accumulation under climate change partly due to increased strength of the Western Disturbances in HadCM3. However, over the 21st century the warming trend and corresponding increased ablation is likely to dominate any increase in accumulation leading to reduced mass balance. Despite this, glaciers in this region seem to be less vulnerable to climate change than those in the east. There is considerably uncertainty in the regional detail and ECHAM5 does not capture the increasing snowfall trend in the KK, instead showing a more complex response of an initial increase for moderate warming with an overall decrease at higher levels of warming. The implication is that mitigation of climate change at moderate levels may avoid some of the long-term projected loss of glacier ice in the region. Climate variability, particularly in snowfall and precipitation is a large factor in the overall trends in precipitation and snowfall. Thus, an analysis based on short-term observations may not fully capture the signal of climate change.

The impact of climate change on renewable water resources is likely to be positive in the eastern HKH mainly due to the increase in precipitation over the 21 st century. The direct impact of climate change on water resources may therefore be more important than the glaciological contribution. This is despite the projected greater impact on the glaciers of the eastern region from climate change. However, the western HKH and the Indus will possibly see a decrease in precipitation. Water sourced from glacier melt may therefore be of more importance to this highly populated catchment and thus will be more sensitive in terms of water resources to the projected long-term glacial loss. 
Acknowledgements. This work has been supported by the HighNoon project funded by the European Commission Framework Programme 7 under Grant No. 227087. A. J. Wiltshire of the Met Office Hadley Centre was partly supported by the Joint DECC/Defra Met Office Hadley Centre Climate Programme (GA01101). Jeff Ridley, Camilla Mathison and Jemma Gornall offered useful comments during the preparation of this manuscript. Camilla Mathison set up and ran the RCM simulations. I would also like to thank the reviewers and editor whose comments have significantly improved the paper.

Edited by: T. Bolch

\section{References}

Akhtar, M., Ahmad, N., and Booij, M. J.: The impact of climate change on the water resources of Hindukush-KarakorumHimalaya region under different glacier coverage scenarios, J. Hydrol., 355, 148-163, 2008.

Annamalai, H., Hamilton, K., and Sperber, K. R.: The South Asian summer monsoon and its relationship with ENSO in the IPCC AR4 simulations, J. Climate, 20, 1071-1092, doi:10.1175/Jcli4035.1, 2007.

Arendt, A., Bolch, T., Cogley, J. G., Gardner, A., Hagen, J.-O., Hock, R., Kaser, G., Pfeffer, W. T., Moholdt, G., Paul, F., Radić, V., Andreassen, L., Bajracharya, S., Beedle, M., Berthier, E., Bhambri, R., Bliss, A., Brown, I., Burgess, E., Burgess, D., Cawkwell, F., Chinn, T., Copland, L., Davies, B., De Angelis, H., Dolgova, E., Filbert, K., Forester, R., Fountain, A., Frey, H., Giffen, B., Glasser, N., Gurney, S., Hagg, W., Hall, D., Haritashya, U. K., Hartmann, G., Helm, C., Herreid, S., Howat, I., Kapustin, G., Khromova, T., Kienholz, C., Koenig, M., Kohler, J., Kriegel, D., Kutuzov, S., Lavrentiev, I., LeBris, R., Lund, J., Manley, W., Mayer, C., Miles, E., Li, X., Menounos, B., Mercer, A., Moelg, N., Mool, P., Nosenko, G., Negrete, A., Nuth, C., Pettersson, R., Racoviteanu, A., Ranzi, R., Rastner, P., Rau, F., Raup, B. H., Rich, J., Rott, H., Schneider, C., Seliverstov, Y., Sharp, M., Sigurðsson, O., Stokes, C., Wheate, R., Winsvold, S., Wolken, G., Wyatt, F., and Zheltyhinan N.: Randolph Glacier Inventory [v2.0]: A Dataset of Global Glacier Outlines. Global Land Ice Measurements from Space, Boulder Colorado, USA, Digital Media, 2012.

Barnett, T. P., Adam, J. C., and Lettenmaier, D. P.: Potential impacts of a warming climate on water availability in snow-dominated regions, Nature, 438, 303-309, 2005.

Bhutiyani, M. R.: Mass-balance studies on Siachen Glacier in the Nubra valley, Karakoram Himalaya, India, J. Glaciol., 45, 112118, 1999.

Bolch, T., Pieczonka, T., and Benn, D. I.: Multi-decadal mass loss of glaciers in the Everest area (Nepal Himalaya) derived from stereo imagery, The Cryosphere, 5, 349-358, doi:10.5194/tc-5349-2011, 2011.

Bolch, T., Kulkarni, A., Kääb, A., Huggel, C., Paul, F., Cogley, J. G., Frey, H., Kargel, J. S., Fujita, K., Scheel, M., Bajracharya, S., and Stoffel, M.: The State and Fate of Himalayan Glaciers, Science, 336, 310-314, 2012.

Bookhagen, B. and Burbank, D. W.: Topography, relief, and TRMM-derived rainfall variations along the Himalaya, Geophys. Res. Lett., 33, L08405, doi:10.1029/2006GL026037, 2006.
Bookhagen, B. and Burbank, D. W.: Toward a complete Himalayan hydrological budget: Spatiotemporal distribution of snowmelt and rainfall and their impact on river discharge, J. Geophys. Res.Earth, 115, F03019, doi:10.1029/2009JF001426, 2010.

Christensen, J. H., Hewitson, B., Busuioc, A., Chen, A., Gao, X., Held, I., Jones, R., Kolli, R. K., Kwon, W.-T., Laprise, R., Rueda, V. M., Mearns, L., Menéndez, C. G., Räisänen, J., Rinke, A., Sarr, A., and Whetton, P.: Regional Climate Projections, in: Climate Change 2007: The Physical Science Basis. Contribution of Working Group I to the Fourth Assessment Report of the Intergovernmental Panel on Climate Change, edited by: Solomon, S. Qin, D., Manning, M., Chen, Z., Marquis, M., Averyt, K. B., Tignor, M., and Miller, H. L., Cambridge University Press, Cambridge, United Kingdom and New York, NY, USA, 2007.

Cogley, J. G.: A more complete version of the World Glacier Inventory, Ann. Glaciol., 50, 32-38, 2010.

Cogley, J. G., Kargel, J. S., Kaser, G., and Van der Veen, C. J.: Tracking the Source of Glacier Misinformation, Science, 327, 522-522, 2010.

Collier, E., Mölg, T., Maussion, F., Scherer, D., Mayer, C., and Bush, A. B. G.: High-resolution interactive modelling of the mountain glacier-atmosphere interface: an application over the Karakoram, The Cryosphere, 7, 779-795, doi:10.5194/tc-7-7792013, 2013.

Collins, D.: Climatic warming, glacier recession and runoff from Alpine basins after the Little Ice Age maximum, Ann. Glaciol., 48, 119-124, 2008.

Copland, L., Sylvestre, T., Bishop, M. P., Shroder, J. F., Seong, Y. B., Owen, L. A., Bush, A., and Kamp, U.: Expanded and Recently Increased Glacier Surging in the Karakoram, Arct. Antarct. Alp. Res., 43, 503-516, 2011.

Cruz, R. V., Harasawa, H., Lal, M., Wu, S., Anokhin, Y., Punsalmaa, B., Honda, Y., Jafari, M., Li, C., and Ninh, N. H.: Asia, in: Climate Change 2007: Impacts, Adaptation and Vulnerability. Contribution of Working Group II to the Fourth Assessment Report of the Intergovernmental Panel on Climate Change, edited by: Parry, M. L., Canziani, O. F., Palutikof, J. P., Linden, P. J. v. d., and Hanson, C. E., Cambridge University Press, Cambridge, Cambridge, UK, 469-506, 2007.

Danielson, J. J. and Gesch, D. B.: Global multi-resolution terrain elevation data 2010 (GMTED2010), US Geological Survey OpenFile Report 2011-1073, p. 26, 2011.

Dee, D. P., Uppala, S. M., Simmons, A. J., Berrisford, P., Poli, P., Kobayashi, S., Andrae, U., Balmaseda, M. A., Balsamo, G., Bauer, P., Bechtold, P., Beljaars, A. C. M., van de Berg, L., Bidlot, J., Bormann, N., Delsol, C., Dragani, R., Fuentes, M., Geer, A. J., Haimberger, L., Healy, S. B., Hersbach, H., Holm, E. V., Isaksen, L., Kallberg, P., Kohler, M., Matricardi, M., McNally, A. P., Monge-Sanz, B. M., Morcrette, J. J., Park, B. K., Peubey, C., de Rosnay, P., Tavolato, C., Thepaut, J. N., and Vitart, F.: The ERA-Interim reanalysis: configuration and performance of the data assimilation system, Q. J. Roy. Meteor. Soc., 137, 553-597, 2011.

Dimri, A. P., Yasunari, T., Wiltshire, A., Kumar, P., Mathison, C., Ridley, J., and Jacob, D.: Application of regional climate models to the Indian winter monsoon over the western Himalayas, Sci. Total Environ., 468, S36-S47, 2013. 
Essery, R. L. H., Best, M. J., Betts, R. A., Cox, P. M., and Taylor, C. M.: Explicit representation of subgrid heterogeneity in a GCM land surface scheme, J. Hydrometeorol., 4, 530-543, 2003.

Fowler, H. J. and Archer, D. R.: Conflicting signals of climatic change in the Upper Indus Basin, J. Climate, 19, 4276-4293, 2006.

Fujita, K.: Effect of precipitation seasonality on climatic sensitivity of glacier mass balance, Earth Planet. Sc. Lett., 276, 14-19, 2008a.

Fujita, K.: Influence of precipitation seasonality on glacier mass balance and its sensitivity to climate change, Ann. Glaciol., 48, 88-92, 2008b.

Fujita, K. and Nuimura, T.: Spatially heterogeneous wastage of Himalayan glaciers, P. Natl. Acad. Sci. USA, 108, 14011-14014, 2011.

Gardelle, J., Berthier, E., and Arnaud, Y.: Slight mass gain of Karakoram glaciers in the early twenty-first century, Nat. Geosci., 5, 322-325, 2012.

Gardelle, J., Berthier, E., Arnaud, Y., and Kääb, A.: Region-wide glacier mass balances over the Pamir-Karakoram-Himalaya during 1999-2011, The Cryosphere, 7, 1263-1286, doi:10.5194/tc7-1263-2013, 2013.

Gardner, A. S., Moholdt, G., Cogley, J. G., Wouters, B., Arendt, A. A., Wahr, J., Berthier, E., Hock, R., Pfeffer, W. T., Kaser, G., Ligtenberg, S. R. M., Bolch, T., Sharp, M. J., Hagen, J. O., van den Broeke, M. R., and Paul, F.: A Reconciled Estimate of Glacier Contributions to Sea Level Rise: 2003 to 2009, Science, 340, 852-857, 2013.

GLIMS: Global Land Ice Measurements from Space glacier database, updated 2013. Compiled and made available by the international GLIMS community and the National Snow and Ice Data Center, Boulder CO, USA, 2005.

Gordon, C., Cooper, C., Senior, C. A., Banks, H., Gregory, J. M., Johns, T. C., Mitchell, J. F. B., and Wood, R. A.: The simulation of SST, sea ice extents and ocean heat transports in a version of the Hadley Centre coupled model without flux adjustments, Clim. Dynam., 16, 147-168, 2000.

Hewitt, K.: The Karakoram anomaly? Glacier expansion and the 'elevation effect,' Karakoram Himalaya, Mt Res Dev, 25, 332340, 2005.

Hewitt, K.: Glacier Change, Concentration, and Elevation Effects in the Karakoram Himalaya, Upper Indus Basin, Mt. Res. Dev., 31, 188-200, 2011.

Hock, R.: Temperature index melt modelling in mountain areas, J. Hydrol., 282, 104-115, 2003.

Hock, R.: Glacier melt: a review of processes and their modelling, Prog. Phys. Geog., 29, 362-391, 2005.

Ikeda, K., Rasmussen, R., Liu, C. H., Gochis, D., Yates, D., Chen, F., Tewari, M., Barlage, M., Dudhia, J., Miller, K., Arsenault, K., Grubisic, V., Thompson, G., and Guttman, E.: Simulation of seasonal snowfall over Colorado, Atmos. Res., 97, 462-477, 2010.

Immerzeel, W. W., van Beek, L. P. H., and Bierkens, M. F. P.: Climate Change Will Affect the Asian Water Towers, Science, 328, 1382-1385, 2010.

IPCC: Climate Change 2007: The Physical Science Basis. Contribution of Working Group I to the Fourth Assessment Report of the Intergovernmental Panel on Climate Change, edited by: Solomon, S., Qin, D., Manning, M., Chen, Z., Marquis, M., Av- eryt, K. B., Tignor, M., and Miller, H. L., Cambridge University Press, Cambridge, UK and New York, NY, USA, 2007.

Jacob, T., Wahr, J., Pfeffer, W. T., and Swenson, S.: Recent contributions of glaciers and ice caps to sea level rise, Nature, 482, 514-518, 2012.

Jeelani, G., Feddema, J. J., van der Veen, C. J., and Stearns, L.: Role of snow and glacier melt in controlling river hydrology in Liddar watershed (western Himalaya) under current and future climate, Water Resour. Res., 48, W12508, doi:10.1029/2011WR011590, 2012.

Kääb, A., Berthier, E., Nuth, C., Gardelle, J., and Arnaud, Y.: Contrasting patterns of early twenty-first-century glacier mass change in the Himalayas, Nature, 488, 495-498, 2012.

Kang, I. S., Jin, K., Wang, B., Lau, K. M., Shukla, J., Krishnamurthy, V., Schubert, S. D., Wailser, D. E., Stern, W. F., Kitoh, A., Meehl, G. A., Kanamitsu, M., Galin, V. Y., Satyan, V., Park, C. K., and Liu, Y.: Intercomparison of the climatological variations of Asian summer monsoon precipitation simulated by 10 GCMs, Clim. Dynam., 19, 383-395, 2002.

Kang, S. C., Xu, Y. W., You, Q. L., Flugel, W. A., Pepin, N., and Yao, T. D.: Review of climate and cryospheric change in the Tibetan Plateau, Environ. Res. Lett., 5, 015101, doi:10.1088/17489326/5/1/015101, 2010.

Kaser, G., Grosshauser, M., and Marzeion, B.: Contribution potential of glaciers to water availability in different climate regimes, P. Natl. Acad. Sci. USA, 107, 20223-20227, 2010.

Kripalani, R. H., Oh, J. H., Kulkarni, A., Sabade, S. S., and Chaudhari, H. S.: South Asian summer monsoon precipitation variability: Coupled climate model simulations and projections under IPCC AR4, Theor. Appl. Climatol., 90, 133-159, 2007.

Kumar, K. R., Sahai, A. K., Kumar, K. K., Patwardhan, S. K., Mishra, P. K., Revadekar, J. V., Kamala, K., and Pant, G. B.: High-resolution climate change scenarios for India for the $21 \mathrm{st}$ century, Curr. Sci., 90, 334-345, 2006.

Kumar, P., Wiltshire, A., Mathison, C., Asharaf, S., Ahrens, B., Lucas-Picher, P., Christensen, J. H., Gobiet, A., Saeed, F., Hagemann, S., and Jacob, D.: Downscaled climate change projections with uncertainty assessment over India using a high resolution multi-model approach, Sci. Total Environ., 468, S18-S30, 2013.

Liu, X. D. and Chen, B. D.: Climatic warming in the Tibetan Plateau during recent decades, Int. J. Climatol., 20, 1729-1742, 2000.

Lucas-Picher, P., Christensen, J. H., Saeed, F., Kumar, P., Asharaf, S., Ahrens, B., Wiltshire, A., Jacob, D., and Hagemann, S.: Can regional climate models represent the Indian monsoon?, J. Hydrometeorol., 12, 849-868, doi:10.1175/2011jhm1327.1, 2011.

Mathison, C., Wiltshire, A. J., Dimri, A. P., Falloon, P., Jacob, D., Kumar, P., Moors, E., Ridley, J., Siderius, C., Stoffel, M., and Yasunari, T.: Regional Projections of North Indian Climate for Adaptation Studies, Sci. Total Environ., 468, S4-S17. 2013.

Maussion, F., Scherer, D., Finkelnburg, R., Richters, J., Yang, W., and Yao, T.: WRF simulation of a precipitation event over the Tibetan Plateau, China - an assessment using remote sensing and ground observations, Hydrol. Earth Syst. Sci., 15, 1795-1817, doi:10.5194/hess-15-1795-2011, 2011.

Maussion, F., Scherer, D., Mölg, T., Collier, E., Curio, J., and Finkelnburg, R.: Precipitation Seasonality and Variability over the Tibetan Plateau as Resolved by the High Asia Reanalysis*, J. Climate, 27, 1910-1927, doi:10.1175/JCLI-D-13-00282.1, 2014. 
Meehl, G. A., Stocker, T. F., Collins, W. D., Friedlingstein, P., Gaye, A. T., Gregory, J. M., Kitoh, A., Knutti, R., Murphy, J. M., Noda, A., Raper, S. C. B., Watterson, I. G., Weaver, A. J., and Zhao, Z.C.: Global Climate Projections, in: The Physical Science Basis. Contribution of Working Group I to the Fourth Assessment Report of the Intergovernmental Panel on Climate Change, edited by: Solomon, S., Qin, D., Manning, M., Chen, Z., Marquis, M., Averyt, K. B., Tignor, M., and Miller, H. L., Cambridge University Press, Cambridge, UK and New York, NY, USA, 2007.

Molg, T. and Kaser, G.: A new approach to resolving climate-cryosphere relations: Downscaling climate dynamics to glacier-scale mass and energy balance without statistical scale linking, J. Geophys. Res.-Atmos., 116, D16101, doi:10.1029/2011JD015669, 2011.

Moors, E. J., Groot, A., Biemans, H., van Scheltinga, C. T., Siderius, C., Stoffel, M., Huggel, C., Wiltshire, A., Mathison, C., Ridley, J., Jacob, D., Kumar, P., Bhadwal, S., Gosain, A., and Collins, D. N.: Adaptation to changing water resources in the Ganges basin, northern India, Environmental Science \&amp; Policy, 14, 758769, doi:10.1016/j.envsci.2011.03.005, 2011.

Nakicenovic, N., Alcamo, J., Davis, G., de Vries, B., Fenhann, J., Gaffin, S., Gregory, K., Grübler, A., Jung, T. Y., Kram, T., La Rovere, E. L., Michaelis, L., Mori, S., Morita, T., Pepper, W., Pitcher, H., Price, L., Riahi, K., Roehr, 1. A., Rogner, H.-H., Sankovski, A., Schlesinger, M., Shukla, P., Smith, S., Swart, R., van Rooijen, S., Nadejda, V., and Dadi, Z.: IPCC Special report on emissions scenarios, Cambridge, UK, 2006.

Neckel, N., Kropáček, J., Bolch, T., and Hochschild, V.: Glacier mass changes on the Tibetan Plateau 2003-2009 derived from ICESat laser altimetry measurements, Environ. Res. Lett., 9, 014009, doi:10.1088/1748-9326/9/1/014009, 2014.

Nuimura, T., Fujita, K., Yamaguchi, S., and Sharma, R. R.: Elevation changes of glaciers revealed by multitemporal digital elevation models calibrated by GPS survey in the Khumbu region, Nepal Himalaya, 1992-2008, J. Glaciol., 58, 648-656, 2012.

Ohmura, A.: Physical basis for the temperature-based melt-index method, J. Appl. Meteorol., 40, 753-761, 2001.

Pope, V. D., Gallani, M. L., Rowntree, P. R., and Stratton, R. A.: The impact of new physical parametrizations in the Hadley Centre climate model: HadAM3, Clim. Dynam., 16, 123-146, 2000.

Putkonen, J. K.: Continuous snow and rain data at 500 to $4400 \mathrm{~m}$ altitude near Annapurna, Nepal, 1999-2001, Arct. Antarct. Alp. Res., 36, 244-248, 2004.

Qin, J., Yang, K., Liang, S. L., and Guo, X. F.: The altitudinal dependence of recent rapid warming over the Tibetan Plateau, Clim. Change, 97, 321-327, 2009.

Rabatel, A., Francou, B., Soruco, A., Gomez, J., Cáceres, B., Ceballos, J. L., Basantes, R., Vuille, M., Sicart, J.-E., Huggel, C., Scheel, M., Lejeune, Y., Arnaud, Y., Collet, M., Condom, T., Consoli, G., Favier, V., Jomelli, V., Galarraga, R., Ginot, P., Maisincho, L., Mendoza, J., Ménégoz, M., Ramirez, E., Ribstein, P., Suarez, W., Villacis, M., and Wagnon, P.: Current state of glaciers in the tropical Andes: a multi-century perspective on glacier evolution and climate change, The Cryosphere, 7, 81102, doi:10.5194/tc-7-81-2013, 2013.

Radić, V. and Hock, R.: Regional and global volumes of glaciers derived from statistical upscaling of glacier inventory data, J. Geophys. Res.-Earth, 115, F01010, doi:10.1029/2009JF001373, 2010 .
Rajeevan, M., Bhate, J., and Jaswal, A. K.: Analysis of variability and trends of extreme rainfall events over India using 104 years of gridded daily rainfall data, Geophys. Res. Lett., 35, L18707, doi:10.1029/2008GL035143, 2008.

Rasmussen, R., Liu, C. H., Ikeda, K., Gochis, D., Yates, D., Chen, F., Tewari, M., Barlage, M., Dudhia, J., Yu, W., Miller, K., Arsenault, K., Grubisic, V., Thompson, G., and Gutmann, E.: HighResolution Coupled Climate Runoff Simulations of Seasonal Snowfall over Colorado: A Process Study of Current and Warmer Climate, J. Climate, 24, 3015-3048, 2011.

Raup, B., Racoviteanu, A., Khalsa, S. J. S., Helm, C., Armstrong, R., and Arnaud, Y.: The GLIMS geospatial glacier database: A new tool for studying glacier change, Global Planet. Change, 56, 101-110, 2007.

Ridley, J., Wiltshire, A., and Mathison, C.: More frequent occurrence of westerly disturbances in Karakoram up to 2100, Sci. Total Environ., 468, S31-S35, 2013.

Roeckner, E., Bäuml, G., Bonaventura, L., Brokopf, R., Esch, M., Giorgetta, M., Hagemann, S., Kirchner, I., Kornblueh, L., Manzini, E., Rhodin, A., Schlese, U., Schulzweida, U., and Tompkins, A.: The Atmospheric Circulation model ECHAM 5 Part 1: Model description, Max Plank Institute for Meteorology Report 349, 2003.

Schaner, N., Voisin, N., Nijssen, B., and Lettenmaier, D. P.: The contribution of glacier melt to streamflow, Environ. Res. Lett., 7, 034029, doi:10.1088/1748-9326/7/3/034029, 2012.

Scherler, D., Bookhagen, B., and Strecker, M. R.: Spatially variable response of Himalayan glaciers to climate change affected by debris cover, Nat. Geosci., 4, 156-159, 2011.

Siderius, C., Biemans, H., Wiltshire, A., Rao, S., Franssen, W. H. P., Kumar, P., Gosain, A. K., van Vliet, M. T. H., and Collins, D. N.: Snowmelt contributions to discharge of the Ganges, Sci. Total Environ., 468, S93-S101, 2013.

Singh, P., Kumar, N., and Arora, M.: Degree-day factors for snow and ice for Dokriani Glacier, Garhwal Himalayas, J. Hydrol., 235, 1-11, 2000.

Turner, A. G., Inness, P. M., and Slingo, J. M.: The role of the basic state in the ENSO-monsoon relationship and implications for predictability, Q. J. Roy. Meteor. Soc., 131, 781-804, 2005.

Turner, A. G. and Annamalai, H.: Climate change and the South Asian summer monsoon, Nat. Clim. Change, 2, 587-595, 2012.

US Navy: Fleet Numerical Meteorology and Oceanography Center/U.S. Navy/U. S. Department of Defense U.S. Navy 10Minute Global Elevation and Geographic Characteristics, in, Research Data Archive at the National Center for Atmospheric Research, Computational and Information Systems Laboratory, Boulder, Colorado, 1980.

Ueda, H., Iwai, A., Kuwako, K., and Hori, M. E.: Impact of anthropogenic forcing on the Asian summer monsoon as simulated by eight GCMs, Geophys. Res. Lett., 33, L06703, doi:10.1029/2005GL025336, 2006.

Viviroli, D., Durr, H. H., Messerli, B., Meybeck, M., and Weingartner, R.: Mountains of the world, water towers for humanity: Typology, mapping, and global significance, Water Resour. Res., 43, W07447, doi:10.1029/2006WR005653, 2007.

WWF: An Overview of Glaciers, Glacier Retreat, and Subsequent Impacts in Nepal, India and China, WWF Nepal Program, Kathmandu, 2005. 
Xu, B. Q., Cao, J. J., Hansen, J., Yao, T. D., Joswia, D. R., Wang, N. L., Wu, G. J., Wang, M., Zhao, H. B., Yang, W., Liu, X. Q., and He, J. Q.: Black soot and the survival of Tibetan glaciers, P. Natl. Acad. Sci. USA, 106, 22114-22118, 2009.

Yatagai, A. and Yasunari, T.: Trends and Decadal-Scale Fluctuations of Surface Air-Temperature and Precipitation over China and Mongolia during the Recent 40-Year Period (1951-1990), J. Meteorol. Soc. Jpn, 72, 937-957, 1994.
Yatagai, A., Arakawa, O., Kamiguchi, K., Kawamoto, H., Nodzu, M. I., and Hamada, A.: A 44-Year Daily Gridded Precipitation Dataset for Asia Based on a Dense Network of Rain Gauges, Sola, 5, 137-140, 2009. 